UDC 811:161.1-054.6

DOI: $10.17223 / 24109266 / 11 / 10$

\title{
AUTODIDACTIC APPROACH: FORMING SELF-DIRECTED EFL LEARNING READINESS
}

\author{
N. Sergeeva, A. Guzeva
}

\begin{abstract}
The article deals with the problem of preparing intending EFL teachers at teacher training universities for professionally-oriented selfdirected learning readiness in the field if foreign languages. For this purpose the brief outline of basic characteristics of such a readiness is given on the basis of analysis of scientific literature on the problem. The authors of the article share their positive experience in applying the autodidactic approach to teaching English to students of the English Department in the Institute of Foreign Languages of Ural State Pedagogical University. The research results prove that it is possible to effectively form students' self-directed EFL learning readiness by means of increasing their methodological awareness in the field of teaching foreign languages and applying their knowledge and skills to the process of self-directed learning itself both within and beyond the classroom environment. The three stages of the approach are described in detail: learning, self-directed learning, and peer-teaching. The final stage is considered professionally-oriented since it allows students to act in the capacity of future teachers of English but, here, within the classroom environment. The approach is realized according to five consequent principles: intersubject coordination, tutoring, individually oriented assessment, heuristic and multitasking principles. The principles by their nature go back to the student-centered and activity approach, the integrative-differentiative approach and the contextual approach which serve as the methodological bases of the autodidactic approach developed.
\end{abstract}

Keywords: self-directed learning, peer-teaching, self-directed learning readiness, communicative competence, autodidactic approach, teacher training

\section{Introduction}

What is self-directed EFL learning readiness?

One of the priorities set in the Federal State Educational Standards for higher education in the field of teacher training in Russia deals with making students ready for professionally-oriented self-directed learning in the chosen professional field - EFL teaching in particular [1].

The analysis of scientific literature on psychology and theory of education led to singling out basic characteristics of self-directed learning readiness such as: a) inner formation linked with motives, needs, interests, feelings and emotions [2]; b) a set of abilities making a person suitable for work [3] and enabling him/ her to acquire skills in an activity (studying included) [4]; c) an ability to control and regulate your own actions in accordance with the aim and plan set [5]; d) readiness as the basis for competence as such [6] 
or the basis for professional subjectivity of a person [1]; e) learning preferences [7] and a sense of responsibility for the results achieved [8] etc.

This outline of characteristics gave the possibility to define selfdirected EFL learning readiness as follows: it is a student's ability to use a system of study skills and knowledge in the field of learning a foreign language to cope with individual difficulties in language acquisition and then share his / her own positive experience when teaching and peer-teaching.

Thus, the readiness in question presupposes "knowledge-skills" coordination and its application to solving practice-oriented tasks on a regular basis within and beyond the classroom environment by intending teachers of English.

What makes intending EFL teachers different from other groups of students studying a foreign language as part of their higher educational curriculum?

First of all, time allotment. According to the current curriculum at Ural State Pedagogical University, for example, intending EFL teachers have 1,874 academic hours for the practical course of a foreign language (English) which is 7-8 times as large in comparison with other students getting vocational training in a different professional filed.

Secondly, thorough language training in speaking, listening, reading, writing and many sided specialization that includes teaching (pedagogy, psychology, methodology), theory and practice of translation, linguistic analysis from the standpoints of phonetics, lexicology, grammar, stylistics, general and comparative linguistics etc.

Thirdly, "Teach and Learn" as a corporate motto of the University. It gives us ground to let students apply the motto to practice while learning the language for professional needs.

\section{Problem Statement}

It is possible to effectively form students' self-directed EFL learning readiness at teacher training universities by means of increasing their methodological awareness in the field of teaching foreign languages and applying their knowledge and skills to the process of self-directed learning itself both within and beyond the classroom environment.

\section{Research Questions}

What approach to a foreign language teaching proves to be productive for forming students' self-directed EFL learning?

What is the methodological basis of the chosen approach and its main principles? 
What pedagogical conditions are considered necessary for realization of the approach: students' language level, the course of study, class organization and its stages, didactic and diagnostic materials?

\section{Purpose of the Study}

The purpose of the research is to theoretically prove and develop the autodidactic approach to teaching foreign languages to students' of teacher training universities.

\section{Research Methods}

Different theoretical and empirical methods were used to carry out this research. On the theoretical level they are the analysis of normative documents in higher education and scientific literature on the research problem in question; experience synthesis of pedagogical activity of higher educational establishments; systematization of research work results, modeling method. On the empirical level they are practices-search work; direct observation; testing; questionnaires, methods of mathematical statistics.

\section{Subject (cases)}

The research involved 183 participants aged 18-22, all being students of the Institute of Foreign Languages (English Department) of Ural State Pedagogical University, Yekaterinburg, Russia.

\section{Procedure}

The research was organized in three subsequent stages from 2015 till 2019.

The stage of theoretical analysis (2015-2016) was aimed at the analysis of normative documents in higher education and scientific literature on the research problem. As a result the theoretical basis of the research and a structure-functional model of an autodidactic approach were developed.

The stage of experimental training (2017-2019) was organized on the basis of the Institute of Foreign Languages (English Department) of Ural State Pedagogical University, Yekaterinburg, Russia. The practices-search work included direct observation and preliminary testing of students' selfdirected EFL readiness. The results obtained laid the foundation for the development of didactic materials (handouts, PP presentations) and a textbook "Autodidactic English Learning for Intending EFL Teachers". Then the training itself followed that led to further testing and direct observation of the skills formed. In addition questionnaires were employed for regular 
feedback in the educational process organized. They allowed to systematically improve the methods and materials used.

The stage of result analysis (2019) was realized by means of methods of mathematical statistics which made the obtained results look valid and reliable. The final conclusions on the research problem were drawn.

\section{Findings}

The notion of the autodidactic approach to a foreign language teaching.

The autodidactic approach to a foreign language teaching is an approach based on the integrative studying of a core subject (Practical Course of English) and methods of teaching and aimed at the formation of students' self-directed EFL learning readiness.

Restrictions of the approach are as follows: 1) it is realized at teacher training universities; 2) students are intending EFL teachers; 3) the minimal demanded language level is B1. The approach is implemented in order to help students "acquire a set of techniques to constantly develop their professional competence and skills in the field of EFL teaching and learning" alongside with developing their communicative competence in English [9].

The methodological basis of the autodidactic approach to a foreign language teaching and its main principles.

The methodological basis of the approach can be traced to the studentcentered and activity approach by I.A. Zimnaya [10], the integrativedifferentiative approach by A.V. Gvozdeva [11] and the contextual approach by A.A. Verbitsky [12]; the main principles being intersubject coordination, tutoring, individually oriented assessment, heuristic principle, multitasking. The details are given below.

The student-centered and activity approach by I.A. Zimnaya demands to organize language teaching and learning in the form of subject-subject interpersonal 'teacher-student', 'student-student' interaction during which students shall solve individually-oriented problematic communicative tasks using the target language only. She outlines the following ideas basic for the approach: a) the object of teaching - foreign language speech activity realized in five forms - speaking, listening, reading, writing, and translation (the latter we consider important for intending EFL teachers since it is rarely singled out as a separate speech activity in various courses, both Russian and authentic ones); b) the subject of a speech activity - the process of forming and formulating a thought in a foreign language; c) the product of a speech activity - either a conclusion as a mental construction (when reading or listening) or an utterance (in speaking or writing); translation possessing the characteristics of both receptive and productive speech activities. Zimnaya's approach being an activity approach by nature reflects psycholinguistic views on the structure of a speech activity and outlines its three classical 
stages: motivation, analysis-synthesis, performance. We consider the abovementioned ideas of the student-centered and activity approach by I.A. Zimnaya the key ones for our autodidactic approach as they reflect the true nature of a foreign language communicative competence, i.e. any competence is formed and further developed only within the activity itself.

The integrative-differentiative approach by A.V. Gvozdeva supplies us with the idea of employing integration and differentiation as two alternating processes when learning a foreign language. Integration allows us to follow common aims whereas differentiation makes us do it in different ways catering for students' individual needs and interests. Unlike the individual approach, Gvozdeva's integrative-differentiative approach is group-based and professionally-oriented. It suits the aims and nature of our autodidactic approach to a foreign language teaching and learning at teacher training universities.

The contextual approach by A.A. Verbitsky enriches our approach with the idea of subsequent change of practice- and professionally-oriented models which allow students to gradually get ready for real-life tasks in the chosen professional field, i.e. the field of EFL teaching in our case. The first model is semiotic and aimed at students' work with ESP texts in all kinds of speech activity. It focuses on learning as the primary step of knowledge and skills acquisition. The second model is imitative: students play out professionally-oriented situations within the classroom environment. Project work may come in handy here, too. The third model is social and realized outside the university classroom, i.e. at work - students being in the capacity of 'real' teachers during their block teaching practice.

The cited methodological basis led to singling out specific principles of the autodidactic approach to a foreign language teaching. Thus, the principle of intersubject coordination coordinates language learning with the students' acquisition of methods of teaching which they are encouraged to use for self-directed EFL learning, first and foremost. Here we, as if, keep in mind the statement: "First teach yourself to study a language then you will teach others". The principle of tutoring lets students learn the language by teaching it. Here we take an advantage of them being future teachers and give them a possibility to teach each other in peer-teaching mode. The principle of individually oriented assessment presupposes the use of language portfolio to monitor students' individual progress in learning the target language, their individual difficulties and achievements, and the efforts spent on achieving the result. The heuristic principle allows students' to constantly move ahead despite the fact that some language or methodological material may not have been acquired by them at once at a good level since the content of the autodidactic approach is spiral, meaning time and again we come back to the material studied and employ it for solving new communicative tasks. Finally, the multitasking principle takes into account 'clip-thinking' of the 
so-called "digital generation" of students and requires to organize specially split continuum of a lesson.

Pedagogical conditions necessary for realization of the autodidactic approach.

Students' language level: B1 or higher.

Course of study: Practical Course of English (1.874 academic hours)

Class organization and its stages: the basic cycle that goes on interminably according to the autodidactic approach to a foreign language is "LEARNING - SELF-DIRECTED LEARNING - PEER-TEACHING". The cycle reflects the three stages of class interaction that is aimed at forming students' self-directed EFL learning readiness alongside with the development of their communicative competence in English.

The LEARNING stage is quite traditional: students acquire new knowledge and skills under the guidance of their teacher. The peculiarity of the approach in question is that their language learning intermingles with methodological input on how language teaching and learning work since our students are intending EFL teachers. For this purpose we shall not set learning and teaching apart. Our idea is to let them study "teaching" while learning the language. That is why our work at the given stage of the autodidactic approach runs as follows during a class: engaging - 1st methodological input (presentation) - language learning - 2nd methodological input (copying with individual difficulties) - language learning - $3 \mathrm{~d}$ methodological input (reflection and setting objectives for out-of-class self-directed language learning). Special stress must be laid on the teacher acting as tutor to every student: he / she helps students' discern individual difficulties in language acquisition and learning. The results of this 'teacher-student' cooperative work are registered in language portfolios where a student sees the material that is recommended to him / her by the teacher for independent work outside the classroom environment.

The learning stage is followed by the SELF-DIRECTED LEARNING stage realized out-of-class when students work on their own according to the previously set individual objectives in their portfolios. This stage of training includes the following steps: identifying individual difficulties in language learning and setting objectives; finding the necessary material, methods and techniques for training; training itself; reflection and evaluation.

Finally follows the PEER-TEACHING stage of the autodidactic approach of interaction. It is aimed at giving students an opportunity to apply their knowledge and skills of self-directed EFL learning to practice of professionally oriented activity - teaching, i.e. peer-teaching in fact. Such an interaction with their groupmates may be considered a sort of methodological output (compared to the methodological input at the learning stage) since students are asked to share their own experience of language learning to 34 other students. 
The important link between all three stages is reflection and evaluation, and here we see eye to eye with J. Scrivener: "doing something - recalling what happened - reflecting on that - drawing conclusions from the reflection - using those conclusions to form and prepare for future practical experience" [11].

In addition to the language portfolio, our didactic and diagnostic materials include specially designed tests and questionnaires, and the textbook "Autodidactic English Learning for Intending EFL Teachers". The latter is structured in accordance with the stages of the autodidactic approach to a foreign language and its main idea of merging language learning and teaching from the position of a student. Thus, the three basic parts of the textbook are "Autodidactic Awareness" (which assists students at the stage of learning), "Brush up Your Study Skills" (at the stage of self-directed EFL learning) and "Teach and Learn" (at the stage of peer-teaching).

\section{Conclusion}

The experimental training involved 183 intending EFL teachers, aged 18-22. The analysis of the level of their self-directed EFL learning readiness before and after the training shows its positive dynamics. The readiness under consideration increased in $78 \%$ of the students and ranges from $21-34 \%$. The rest of the study group shows insignificant changes, i.e. from $7-14 \%$ on average. As for qualitative changes, the research results give us evidence that autodidactic approach to a foreign language learning teaches students to better: 1) select the material in accordance with the language difficulties of their "partners" and organize it appropriately; 2) follow attentively their language interaction within the small group, listening to each other; 3) discern and correct mistakes in the speech of others and, consequently, in their own speech; 4) assess the quality of the work done by themselves and others from the linguistic and methodological standpoints with the help of the criteria given in their language portfolios.

Thus, it is here where students' self-directed language learning acquires its status of being professionally oriented, i.e. they come to the idea of learning the language by teaching it and turn out to be ready for it.

\section{References}

1. Bailuk, V.V.: Formirovanie gotovnosti budushchih specialistov v vuze k professionalnoj samorealizacii: monografiya [Formation of readiness of future specialists at university for professional self-realization: monograph]. Ekaterinburg (2016)

2. Leontiev, A.N.: Deyatelnost. Soznanie. Lichnost [Activity. Consciousness. Personality]. M.: Smysl; Izdatelskij centr «Akademiya» (2004)

3. Ananiev, B.G.: Chelovek kak predmet poznaniya [Person as a subject of cognition]. SPb: Piter (2001) 
4. Rubinshtein, S.L.: Osnovy obshchej psihologii [Foundations of general psychology]. Spb.: Piter (2002)

5. Serikov, V.V.: Razvitie lichnosti v obrazovatelnom processe: monografiya [Personality development in the educational process: monograph]. M.: Logos (2012)

6. Khutorskoy, A.V.: Didaktika: Ucheb. dlya vuzov. Standart tretego pokoleniya [Didactics: textbook for universities. Third generation standard]. Spb.: Piter (2017)

7. Guglielmino, L.M., Guglielmino, P.J.: Quick facts about the Self-Directed Learning Readiness Scale (SDLRS). URL: http://www.lpasdlrs.com (Accessed: 12.01.2019).

8. Gyawali, S., Jauhari, A.C., Shankar, P., Ahmad, M.: Readiness For Self Directed Learning Among First Semester Students Of A Medical School In Nepal// Journal of Clinical and Diagnostic Research, Vol. 5 (1). pp. 20-23 (2011)

9. Guzeva, A.I.: Self-directed language learning for intending EFL teachers // Aktualnye problemy professionalnoj sfery $\mathrm{v}$ sovremennom mire / Ural. gos. ped. un-t; pod red. N.N. Sergeevoj. Ekaterinburg, pp. 35-38 (2017)

10. Zimnyaya, I.A.: Lingvopsihologiya rechevoj deyatelnosti [Linguopsychology of speech activity]. M.: Moskovskij psihologo-socialnyj institut, Voronezh; NPO «MODEHK» (2001)

11. Gvozdeva, A.V.: Integrativno-differencirovannyj podhod k razvitiyu sub"ektnosti studentov vuza $\mathrm{v}$ processe obucheniya francuzskomu yazyku [Integratively differentiated approach to the development of subjectivity in university students in the process of teaching French]. Pedagogics doc. diss. Kursk (2009)

12. Verbitsky, A.A.: Lichnostnyj i kompetentnostnyj podhody v obrazovanii: problemy integracii [Personal and competence approaches in education: problems of integration] / A.A. Verbitsky, O.G. Larionova. M.: Logos (2017)

13. Scrivener, J.: Learning Teaching. The Essential Guide to English Language Teaching. Macmillan (2015)

Information about the authors:

Sergeeva N. - D.Sc. (Education), Professor, Head of the Department of Professional-Oriented Language Education at the Ural State Pedagogical University (Ekaterinburg, Russia). E-mail: snatalia2016@mail.ru

Guzeva A. - Assistant of the Department of English Philology and Comparative Linguistics, Ural State Pedagogical University (Yekaterinburg, Russia). E-mail: anna.guzeva2012@mail.ru 